\title{
Distribution of Common Maize Diseases and Molecular Characterization of Maize Streak Virus in Kenya
}

\author{
Alice K. Charles ${ }^{1}$, William M. Muiru ${ }^{1}$, Douglas W. Miano ${ }^{1} \&$ John W. Kimenju ${ }^{1}$ \\ ${ }^{1}$ Department of Plant Science and Crop Protection, University of Nairobi, Nairobi, Kenya \\ Correspondence: Alice K. Charles, Department of Plant Science and Crop Protection, University of Nairobi, \\ Nairobi, Kenya. E-mail: kainyuwatuku@gmail.com
}

Received: April 20, 2018

doi:10.5539/jas.v11n4p47

\author{
Accepted: January 27, $2019 \quad$ Online Published: April 15, 2019 \\ URL: https://doi.org/10.5539/jas.v11n4p47
}

\begin{abstract}
Maize is an important food crop in Kenya and is susceptible to a wide range of diseases. A survey was conducted in 2012 in different agro-ecological zones (AEZ) of Kiambu, Embu and Nakuru counties to determine the distribution of northern leaf blight (NLB), common rust (CR), maize streak disease (MSD), gray leaf spot (GLS), head smut (HS) and common smut (CS). Data collected included prevalence, incidence and severity of each of the diseases. Maize leaf samples infected with MSD were also collected for molecular characterization of Maize streak virus (MSV). Northern leaf blight was reported in all counties surveyed with $100 \%$ disease prevalence. Kiambu had the highest incidence (100\%) of CR whereas Embu had the highest prevalence (45\%) of MSD. The incidences of GLS and HS were very low with averages of below $2.5 \%$. The highest incidence of GLS was in Kiambu (5\%). High altitude areas had higher incidences of NLB and GLS while CS and MSD were widespread in the three counties. Comparison of 797 nucleotides from the open reading frame (ORF) C2/C1 of MSV with other sequences from the GenBank showed sequence similarities of 99 to $100 \%$ with MSV-A strain. The study revealed that the major foliar diseases of maize are widespread in Kenya and therefore there is need to institute measures to manage these diseases and reduce associated losses. Also, the high percent sequence similarities of MSV indicate low variability which is good for breeders since developed resistant varieties can be adopted over a wider region.
\end{abstract}

Keywords: disease incidence, disease severity, diversity, occurrence

\section{Introduction}

Maize (Zea mays L.) is a major cereal crop in the world and ranks third in production after wheat and rice (Muiru et al., 2010; Keya \& Rubaihayo, 2013). Maize is important as a staple food in sub-Saharan Africa (SSA), providing food and income to over 300 million resource-poor smallholder farmers (Tefera et al., 2011). The crop provides high yields per unit of land, making it a key crop in ensuring food availability and security for the consumers (Mboya et al., 2011). Maize is a major staple food in Kenya and is used as a determinant of food security (Tumusiime et al., 2010; Ouma \& De-Groote, 2011). Maize production in Kenya is constrained by both abiotic and biotic factors (Wambugu \& Wafula, 2000). Maximum crop production in the country in a good season is about 34 million tons and it can drop to 18 million tons during drought years (EPZA, 2005).

Gray leaf spot (GLS) caused by Cercospora-zeae maydis, common rust (CR) caused by Puccinia sorghi, northern leaf blight (NLB) caused by Exserohilum turcicum and maize streak disease (MSD) caused by Maize streak virus (MSV) are the most important maize diseases in Kenya (Mwangi, 1998; Muiru, 2008; Kinyua et al., 2010). Yield losses due to GLS range from 10 to $70 \%$ though during epidemics, 90 to $100 \%$ losses have been reported (Nzuve et al., 2013). Maize lethal necrosis (MLN) disease, which is a relatively new disease in the region, has proved to be a major limiting factor in maize production (Wangai et al., 2012). Increased severity of maize diseases in Africa is associated with continuous cultivation and use of susceptible maize cultivars (Danson et al., 2008). Apart from MLN disease which has been extensively studied because of being new in the region, all other maize diseases have received very little attention.

Maize streak disease causes yield losses that range from trace to almost 100\% (Kyetere et al., 1999; Alegbejo et al., 2002). The disease is distributed throughout the African continent and surrounding islands (Monjane et al., 2011) and is one of the most economically significant member of the Geminiviridae family (Bosque-Perez, 2000). Globally MSD is regarded as the third most serious disease of maize after NLB and GLS (Pratt \& Gordon, 
2006). In Africa, however, MSD is a bigger problem than both NLB and GLS (Martin \& Shepherd, 2009). Epidemics resulting in economic losses of up to $100 \%$ have been reported in at least 20 African countries including Nigeria, Ghana, Sudan, Cameroon, Zimbabwe, Tanzania, Togo, Benin, Bukina Faso, Sao Tome, Uganda and Ethiopia (Lagat et al., 2008). In East Africa, MSD has been identified as a major constraint to maize production in Kenya (Magenya et al., 2008; Martin \& Shephered, 2009; Gichuru et al., 2011) and Uganda (Owor, 2008). In Kenya, the disease was reported to be severe in mid-altitude areas and mid highland zones (Lagat et al., 2008). Eleven distinct MSV strains, classified as MSV-A to MSV-K, have been identified, of which only MSV-A are known to be infecting maize, while majority of the rest are adapted to infecting wild grass species (Willment et al., 2001; Monjane et al., 2011). MSV-A has further been subdivided into five subtypes, MSV-A $\mathrm{A}_{1}$ to MSV-A 4 and MSV-A $\mathrm{A}_{6}$, each being reported in different parts of SSA (Varsani et al., 2008; Monjane et al., 2011). MSV-A is the predominant subtype in Uganda (Owor et al., 2007). However, little work has been done to characterize MSV isolates from Kenya.

This study was carried out to assess the distribution, incidence and severity of major maize diseases and to characterize different MSV isolates collected from different maize growing regions of Kenya.

\section{Materials and Methods}

\subsection{Study Area, Determination of Distribution, Incidence and Severity of the Various Diseases}

\subsubsection{Study Area and Assessment of Maize Diseases}

A survey was conducted in 2012 during the tasseling stage in the selected maize growing counties of Kenya represented by Kiambu Upper Midland (UM1, UM2 and UM4), Embu Upper Midland (UM1, UM2 and UM3), and Nakuru Lower Highland (LH2) and Upper Midland (UM3 and UM4). In each AEZ, six diseases were assessed and these included northern leaf blight (NLB), common rust (CR), gray leaf spot (GLS), head smut (HS), common smut (CS) and maize streak disease (MSD). Sampling was carried out in four farms per AEZ approximately two kilometres apart selected at random. Background information was obtained from farmers using a structured questionnaire. The information captured in the questionnaire included size of the farm, area under maize, varieties planted, source of planting materials, cropping systems (pure or mixed stand/inter cropping), stage of crop growth when disease was first noticed, farmers perception of the diseases and the control measures employed by the farmers to manage the diseases. The background information was then summarized as percentages according to farmers' responses.

Disease prevalence was assessed by determining the number of fields where a particular disease was recorded in relation to the number of fields sampled in different AEZ and counties. The scoring for disease incidence and disease severity was done for NLB, CR, GLS, MSV, while for HS and CS, only disease incidence was determined. Identification of the diseases was based on visual symptoms as described in the International Maize and Wheat Improvement Center (CIMMYT) field disease identification guide (CIMMYT, 2004). The distance within sampled plants ranged between 0.5 to 5 metres depending on the size of the farms. The size of the farms ranged from small peasant plots of about 0.25 acres in Kiambu and Embu counties to over 70 acres in Nakuru County. From the plants selected, disease incidence was determined by calculating the percentage of infected plants out of 10 plants taken along x-shaped transects. Disease severity was assessed using specific scoring keys described below.

\subsubsection{Rating Scales Used for Disease Severity Assessment}

Northern leaf blight severity was rated using a modification of a scoring key of 0-5 described by Elliots and Jenkins (1946), where, $0=$ indicates no symptoms, 0.5 = very slight infection (one or two restricted lesions on lower leaves), 1 = slight infection (a few scattered lesions (3-8) on lower leaves, $2=$ light infection (moderate number of lesions [9-15] on lower leaves), $3=$ moderate infection (abundant lesions [ $>16]$ on lower leaves and a few on middle leaves), 4 = heavy infections (lesion abundant on lower and middle leaves and extending to the upper leaves), $5=$ very heavy infection, lesions abundant on all leaves, plants may be killed.

Common rust was assessed using a key adopted from Danson et al. (2008), where, 1 = no symptoms, 2 = a few lesions corresponding to less than $1 \%$ of the leaf area with symptoms, $3=$ several lesions, but not linked together corresponding to $1-5 \%$ infected leaf area, $4=$ many lesions some linked together to form a necrotic (dead) area corresponding to $6-20 \%$ infected leaf area, $5=$ necrotic areas linked together and a few leaf tips are dead corresponding to $21-50 \%$ infected leaf area, $6=50 \%$ of the leaf tips are dead corresponding to more than $50 \%$ leaf area with symptoms, $7=$ most of the leaves are dead or the plant is dead.

Gray leaf spot was assessed using a modified scale by Danson et al. (2008), where, 1 = no symptoms, $2=$ moderate lesion below the leaf subtending the ear, 3 = heavy infestation on and below the leaf subtending the ear 
with few lesions above it, $4=$ severe lesion on all but the uppermost leaves which may have a few lesions, $5=$ all leaves dead.

Maize streak disease severity rating was done using a scoring key modified from Gichuru et al. (2011), where, 1 $=$ no symptoms, $1.5=$ very few streaks on leaves, $2=$ light streaks on old leaves gradually decreasing on young leaves, $2.5=$ light streaking on old and young leaves, $3=$ moderate streaks on old and young leaves, $3.5=$ moderate streaks on old and young leaves and slight stunting, $4=$ severe streaking on $60 \%$ of leaf area, plants stunted, $4.5=$ severe streaking on $75 \%$ of leaf area, plants severely stunted, $5=$ severe streaking on $75 \%$ or more of the leaf area, plants severely stunted and or dying. The data on disease prevalence, incidence and severity was analysed using Genstat $13^{\text {th }}$ Edition statistical program. Analysis of Variance (ANOVA) was used and Fischer's Protected LSD was used to separate the means at $\mathrm{P}=5 \%$.

\subsection{Molecular Characterization of Maize Streak Virus}

\subsubsection{Sample Collection and Nucleic Acid Extraction}

Young leaf samples were collected from maize plants showing MSD symptoms from different maize growing regions of Kenya. Total DNA was extracted from leaf tissue using Dellaporta extraction method (Dellaporta et al., 1983). About $200 \mathrm{mg}$ of leaf tissue was weighed and ground using a mortar and pestle. Five hundred microlitres $(500 \mu \mathrm{l})$ of Dellaporta buffer was added twice to the leaf sample and the mixture crushed into fluid state. The fluid was transferred into labeled microcentrifuge tubes, where $140 \mu 1$ of $10 \%$ Sodium dodecyl sulphate (SDS) was added and the tubes gently inverted in a rack. The samples were incubated in a water bath at $65{ }^{\circ} \mathrm{C}$ for 20 minutes with gentle inversion after which $250 \mu \mathrm{l}$ of $8 \mathrm{M}$ potassium acetate was added and tubes gently inverted. The samples were placed on ice for 10 minutes and then spinned at maximum speed of $14000 \mathrm{rpm}$ for 10 minutes. The supernatant was collected and transferred into sterilized labeled micro centrifuge tubes. The samples were re-suspended in $600 \mu \mathrm{l}$ cold isopropanol $\left(-20^{\circ} \mathrm{C}\right)$. Spinning was done at a speed of $14000 \mathrm{rpm}$ for 5 minutes and the supernatant discarded and the pellets were washed in $200 \mu 1$ of $70 \%$ ethanol. Spinning was done once again at a speed of $14000 \mathrm{rpm}$ for 3 minutes. The ethanol was discarded and the pellets within the micro centrifuge tubes air-dried in a lamina flow hood on dry clean paper towels for 20 minutes. The pellets were re-suspended in $70 \mu \mathrm{l}$ molecular water and stored at $-80^{\circ} \mathrm{C}$ until PCR was done.

\subsubsection{Polymerase Chain Reaction Procedure}

The extracted genomic DNA was amplified by Polymerase Chain Reaction (PCR) using Geminivirus degenerate primers G4F (5'-AGB KKK KBC ATC GST TCG T-3') and G6R (5'-CTG TAC ATC CTC GGG CCA ACA AGA AC-3') which anneal to regions of open reading frame (ORF) $\mathrm{C} 2 / \mathrm{C} 1$ as described by Van Antwerpen and Rutherford (2008). The primers were expected to amplify a 900 base pair (bp) fragment. PCR was performed using a Gene Amp PCR system 9700. Amplifications were performed in $25 \mu \mathrm{l}$ reaction volumes containing $2 \mu \mathrm{l}$ of the DNA extract, $1.25 \mu \mathrm{l}$ and $1.87 \mu \mathrm{l}$ of forward and reverse primers respectively, $0.625 \mu 1$ of $10 \mathrm{mM} \mathrm{dNTP}$ mix, $0.16 \mu \mathrm{l}$ of Taq DNA polymerase, $2.5 \mu \mathrm{l}$ reaction buffer, $3.5 \mu \mathrm{l}$ of $25 \mathrm{mM} \mathrm{MgCl}_{2}$. PCR was run at 35 cycles of $94{ }^{\circ} \mathrm{C}$ for 5 minutes, $60^{\circ} \mathrm{C}$ for 1 minute, $72{ }^{\circ} \mathrm{C}$ for 2 minutes and $72{ }^{\circ} \mathrm{C}$ for 10 minutes. PCR products were assessed by electrophoresis in $1.2 \%$ agarose gels in TBE buffer, stained with ethidium bromide, and viewed under ultraviolet light.

\subsubsection{PCR Product Purification}

PCR products were purified for sequencing using Qiagen kit following manufacturer's instructions (QIAGEN Inc., Valencia, CA). Five (5) volumes of binding buffer (PB) was added to 1 volume of PCR products (100-20) and transferred to Qia-quick column in provided $2 \mathrm{ml}$ collection tube. The sample was applied to the column and spinned for 1 minute. The flow through was discarded and the column returned back in the same tube. Then 0.7 $\mathrm{ml}$ wash buffer (PE) was added to the Qia-quick column and spinned for 1 minute at $13000 \mathrm{rpm}$. The flow through was discarded and placed back to the column in the collection tubes. A short spin was performed to remove residual wash buffer. The columns were placed in clean $1.5 \mathrm{ml}$ micro centrifuge tube, $30 \mu \mathrm{l}$ elution buffer (buffer EB) or molecular grade water (PH7) was added to elute DNA and spinned for 1 minute at 13000 $\mathrm{rpm}$. The eluted DNA was used for sequencing.

\subsubsection{Sequencing, Sequence Alignment and Phylogenetic Analysis}

Nucleotide sequences were determined at Biosciences for East and Central Africa (BecA), ILRI, Kenya. The obtained sequences comprising of 797 nucleotides fragment from ORF $\mathrm{C} 1 / \mathrm{C} 2$ were compared with corresponding sequences of other MSV infecting maize obtained from the GenBank. Relationships between the different nucleotide sequences from the Kenyan isolates and others obtained from GenBank were analyzed based on a 797 nucleotide fragment from ORF C1 and C2 nucleotide sequences. The sequences and their accession 
numbers are listed in Table 1. Percent nucleotide identities were determined using pairwise global alignment. The alignments were used to determine the percent nucleotide sequence identity using ClustalX version 1.83 procedure (Jeanmougin et al., 1998). Multiple sequence alignments and phylogenetic analysis using neighbor-joining and bootstrap option (1000 replicates) were carried out using MEGA4 (Tamura et al., 2007).

Table 1. GenBank accession numbers for MSV sequences used in this study

\begin{tabular}{|c|c|c|}
\hline Isolate & GenBank accession number & Origin \\
\hline MSVA_CM_Baf1_Cam11 & HQ693319 & Cameroon \\
\hline MSVA_CF_Bim1_Car16 & HQ693305 & Central African Republic \\
\hline Bambui_MB1K1 & FM210279 & Cameroon \\
\hline UBush_53 & EF547075 & Uganda \\
\hline UMasin_149 & EF547098 & Uganda \\
\hline MSVA_MZ_Pem4_Moz40 & HQ693365 & Mozambique \\
\hline MSVA_CM_Baf4_Cam19 & HQ693322 & Cameroon \\
\hline MSVA_CF_Yal1_Car32 & HQ693317 & Central African Republic \\
\hline MSVA_BF_Lou1_BF5 & HQ693282 & Burkina Faso \\
\hline MSVA_ZW_Mas4_Mic6 & FJ882145 & Zimbabwe \\
\hline MSVA_ZM_Chi1_Z6 & HQ693450 & Zambia \\
\hline MSVA_KE_Nye1_Ken11 & HQ693332 & Kenya \\
\hline MSVA_KE_Nan2_Ke2 & HQ693330 & Kenya \\
\hline MSVA_KE_Nan1_Ke3 & HQ693329 & Kenya \\
\hline MSVA_CM_Baf6_Cam23 & HQ693324 & Cameroon \\
\hline MSVA_NG_Eji3N29a & HQ693371 & Nigeria \\
\hline MSVA_NG_Ile_N34 & HQ693382 & Nigeria \\
\hline $\mathrm{k} 40$ & Test isolate & Kenya \\
\hline k39 & Test isolate & Kenya \\
\hline k38 & Test isolate & Kenya \\
\hline k37 & Test isolate & Kenya \\
\hline MSV-K_Zw-Mic23 & EU628644 & Zimbabwe \\
\hline
\end{tabular}

\section{Results}

\subsection{Distribution, Incidence and Severity of Maize Diseases}

\subsubsection{Farmers' Knowledge on Maize Diseases and Their Management}

All the farmers interviewed in Embu County during the survey indicated that they plant maize in pure stand, while those in Kiambu and Nakuru plant maize both in pure and mixed cropping (Table 2). A high percentage of farmers in Embu (71\%) managed the diseases while only 14\% of farmers in Embu and Nakuru were doing it. For those that were managing diseases in Embu, $80 \%$ did it by spraying while $50 \%$ rogued the infected plants. In Kiambu the farmers did not spray while 50\% uprooted and 35\% did nothing (Table 2). In Nakuru 20\% managed the disease through spraying and the rest did not use any management strategy. The highest number of farmers who planted local varieties was in Kiambu at $70 \%$ while Embu had a much lower frequency and Nakuru had none. Most of the hybrids are planted in Nakuru and some of them like KH 500 9A and Lentet were reported only in the county (Table 3). 
Table 2. Farming practices, knowledge on maize diseases and management options adopted by maize farmers in survey areas

\begin{tabular}{|c|c|c|c|}
\hline & \multicolumn{3}{|c|}{ Counties } \\
\hline & Embu & Kiambu & Nakuru \\
\hline \multicolumn{4}{|l|}{ Mode of cultivation } \\
\hline Pure stand & 100.0 & 0 & 0 \\
\hline Mixed stand & 62.5 & 12.5 & 25.0 \\
\hline Both & 29.5 & 31.7 & 39.0 \\
\hline \multicolumn{4}{|c|}{ Season when disease are more severe } \\
\hline Rainy season & 42.9 & 42.9 & 14.3 \\
\hline Dry season & 50.0 & 22.2 & 27.8 \\
\hline Both & 0 & 100.0 & 0 \\
\hline Not observed & 0 & 33.3 & 66.7 \\
\hline \multicolumn{4}{|c|}{ Farmers perception on diseases } \\
\hline Serious & 60.0 & 30.0 & 10.0 \\
\hline Moderately serious & 50.0 & 0 & 50.0 \\
\hline Not serious & 17.2 & 34.5 & 48.3 \\
\hline \multicolumn{4}{|c|}{ Disease control/management done } \\
\hline Yes & 71.4 & 14.3 & 14.3 \\
\hline No & 21.2 & 36.4 & 42.4 \\
\hline Not applicable & 0 & 0 & 100.0 \\
\hline \multicolumn{4}{|c|}{ Measures taken to manage } \\
\hline Spray & 80.0 & 0 & 20.0 \\
\hline Uproot & 50.0 & 50.0 & 0 \\
\hline Not observed & 20.6 & 35.3 & 44.1 \\
\hline
\end{tabular}

Table 3. Percentage of farmers planting various varieties of maize in three counties surveyed

\begin{tabular}{llll}
\hline \multirow{2}{*}{ Variety } & \multicolumn{3}{c}{ Counties } \\
\cline { 2 - 4 } & Embu & Kiambu & Nakuru \\
\hline H513 & 26.3 & 42.1 & 31.6 \\
DH04 & 0 & 25.0 & 75.0 \\
Pioneer & 25.0 & 37.5 & 37.5 \\
Local & 30.0 & 70.0 & 0 \\
H614 & 36.8 & 15.8 & 47.4 \\
Pannar & 0 & 71.4 & 28.6 \\
Nduma 43 & 50.0 & 50.0 & 0 \\
DK8031 & 60.0 & 40.0 & 0 \\
H625 & 0 & 100.0 & 0 \\
H629 & 0 & 100.0 & 0 \\
H624 & 33.3 & 33.3 & 33.3 \\
DK21 & 100.0 & 0 & 0 \\
DK3831 & 100.0 & 0 & 0 \\
H628 & 50.0 & 0 & 50.0 \\
H522 & 100.0 & 0 & 0 \\
H6213 & 0 & 0 & 100.0 \\
KH Lentet & 0 & 0 & 100.0 \\
KH 500 9A & 0 & 0 & 100.0 \\
KH 22 & 0 & 0 & 100.0 \\
KDVT 90031 & 0 & 0 & 100.0 \\
Yellow maize & 0 & 100.0 \\
\hline
\end{tabular}




\subsubsection{Disease Prevalence}

Northern leaf blight, common rust of maize and maize streak disease were the three most commonly reported diseases in all the counties (Table 4). There were no significant differences $(\mathrm{P}<0.05)$ in northern leaf blight prevalence in Embu County within the different agro-ecological zones. In Kiambu, there was a significant difference $(\mathrm{P}<0.05)$ in prevalence between UM1 and UM2 and also between UM2 and UM4, while no significant differences $(\mathrm{P}<0.05)$ were observed between UM1 and UM4. The occurrence of the disease in Embu was recorded in all the agro-ecological zones with UM1, UM2 and UM3 having 95\%, 92.5\% and 97.5\%, respectively. In Nakuru, there were no significant differences within the agro-ecological zones LH2, UM3 and UM4 with average prevalence of $87.5 \%, 82.5 \%$ and $72.5 \%$, respectively.

For common rust in Embu County, there was no significant difference within the agro ecological zones. In Kiambu, a significant difference was observed between UM1 and UM2 with 100 and $15 \%$ prevalence, respectively. A significant difference $(\mathrm{P}<0.05)$ was also observed between UM1 and UM4 in Kiambu County. In Nakuru there were no significant differences for common rust between the various agro-ecological zones.

There were significant differences $(\mathrm{P}<0.05)$ in MSV prevalence in Embu County between UM1 and UM2 and also between UM1 and UM3 while in Kiambu there was no significant difference within the agro-ecological zones. In Nakuru, there was no significant difference observed within the zones. Gray leaf spot had low percentages of 5 in Kiambu UM3 and 7.5 in Embu UM1. Common smut was observed in Kiambu and Embu only with low prevalence ranging between 2.6 and $6 \%$ (Table 4 ).

Table 4. Percentage disease prevalence for NLB, common rust, GLS, maize streak and smut in different AEZs in Kiambu, Embu and Nakuru Counties

\begin{tabular}{lllllll}
\hline County & AEZ & NLB & Common rust & GLS & MSD & Common smut \\
\hline Embu & UM1 & 95.0 & 70.0 & 0 & 45.0 & 0 \\
& UM2 & 92.5 & 57.0 & 0 & 15.0 & 2.5 \\
& UM3 & 97.5 & 75.0 & 5.0 & 12.0 & 0 \\
\hline LSD & & 15.55 & 47.30 & 5.33 & 28.59 & 4.61 \\
\hline Kiambu & UM1 & 95.0 & 100.0 & 7.5 & 35.0 & 5.0 \\
& UM2 & 30.0 & 15.0 & 0 & 22.0 & 5.0 \\
\hdashline LSD & UM4 & 87.0 & 57.0 & 0 & 22.0 & 0 \\
\hline Nakuru & LH2 & 87.5 & 92.5 & 0 & 15.0 & 0 \\
& UM3 & 82.5 & 97.5 & 0 & 15.0 & 0 \\
\hdashline LSD & UM4 & 72.5 & 90.0 & 0 & 2.5 & 0 \\
\hline
\end{tabular}

Note. AEZ $=$ Agro-Ecological Zones, $\mathrm{UM}=$ Upper Midland, $\mathrm{LH}=$ Lower Highland, NLB $=$ Northern Leaf Blight, GLS = Gray Leaf Spot, MSD = Maize streak disease, $\mathrm{CR}=$ Common rust, $\mathrm{HS}=$ Head smut, $\mathrm{CS}=$ Common smut.

Summary of disease prevalence for all the agro ecological zones is shown in Figure 1. The most common diseases observed in all the agro-ecological zones were NLB, common rust and MSD. Two diseases, NLB and common rust, had $100 \%$ disease prevalence in UM1. NLB, common rust and MSD were observed in all the farms. Gray leaf spot and common smut had percentage prevalence below 40 and no significant difference between the two diseases. There was a significant difference in prevalence between NLB and rust and other diseases (MSD, GLS and head smut) in UM2.

There was a significant difference in prevalence between the two main diseases (NLB and common rust) and MSD in UM3. In UM4 again a significant difference was observed between NLB, common rust and MSV. Gray leaf spot was significantly different from the other three diseases (NLB, common rust and MSD). Only three diseases were observed in LH2 namely NLB, common rust and MSD and MSD was significantly different from the other two (Figure 1).

\subsubsection{Disease Incidence}

Significant differences $(\mathrm{P}<0.05)$ were observed in the incidence of northern leaf blight in different zones of Kiambu County whereas no significant difference was observed in Embu and Nakuru counties $(p<0.05)$ (Table 
5). An observation was made in Kiambu County (UM2) where percentage incidence was low for all the diseases compared to the other AEZs. Common rust of maize had a similar trend where significant differences $(p<0.05)$ in incidence were observed in Kiambu but not in Embu and Nakuru counties. There was no significant difference $(p<0.05)$ in incidence observed within the agro ecological zones in any of the counties for maize streak disease, gray leaf spot, head smut and common smut.

Disease incidences of GLS, head smut and common smut were below $10 \%$ across the agro ecological zones, and a significant difference $(\mathrm{p}<0.05)$ was observed between these three diseases. The disease incidence was generally low for all diseases in UM2 compared to other agro-ecological zones. There was a significant difference $(\mathrm{p}<0.05)$ in incidence between the three major diseases, NLB, common rust and MSD in UM2. In UM1, there was a significant difference $(\mathrm{p}<0.05)$ in incidence between MSD and common rust but no significant difference between NLB and common rust. A similar trend was observed in UM3, UM4 and LH2 (Figure 2).

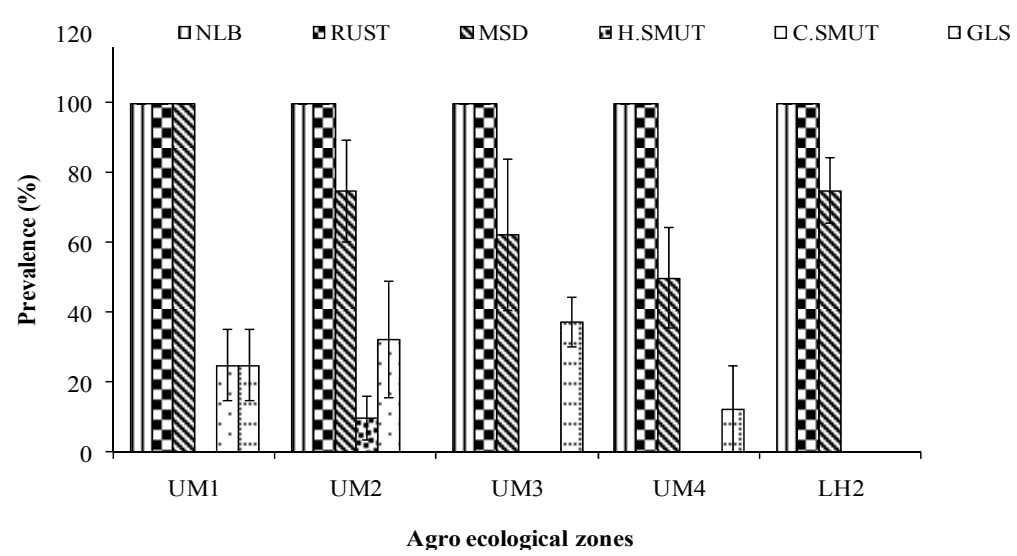

Figure 1. Prevalence of most common maize diseases from different agro ecological zones surveyed in Kenya Note. $\mathrm{AEZ}=$ Agro-ecological zones, $\mathrm{UM}=$ Upper midland, $\mathrm{LH}=$ Lower highland, NLB $=$ Northern leaf blight, GLS $=$ Gray leaf spot, MSD = Maize streak disease, $\mathrm{HS}=$ Head smut, $\mathrm{CS}=$ Common smut.

Table 5. Mean disease incidence of NLB, common rust, GLS, maize streak disease and smut in different AEZs in Kiambu, Embu and Nakuru counties

\begin{tabular}{llllllll}
\hline County & AEZ & NLB & CR & GLS & MSD & HS & CS \\
\hline Kiambu & UM1 & 95.0 & 100.0 & 7.5 & 35.0 & 0 & 5.0 \\
& UM2 & 30.0 & 15.0 & 0 & 25.5 & 0 & 5.0 \\
& UM4 & 87.5 & 57.0 & 0 & 22.5 & 0 & 0 \\
& p-value & 0.02 & 0.001 & 0.17 & 0.73 & 0 & 0 \\
& \%CV & 33.40 & 12.0 & 221.10 & 94.20 & 0 & 0 \\
\hline Embu & LSD & 40.88 & 11.89 & 9.56 & 43.45 & 0 & 0 \\
& UM1 & 95.0 & 70.0 & 0 & 45.0 & 0 & 0 \\
& UM2 & 92.5 & 57.5 & 0 & 15.0 & 0 & 2.5 \\
& UM3 & 97.5 & 75.0 & 5.0 & 12.5 & 0 & 0 \\
& p-value & 0.82 & 0.67 & 0.13 & 0.11 & 0 & 0.42 \\
& \%CV & 11.80 & 40.50 & 200.0 & 83.60 & 0 & 0 \\
& LSD & 19.34 & 47.30 & 5.77 & 34.96 & 0 & 0 \\
\hline Nakuru & LH2 & 83.70 & 91.30 & 0 & 12.50 & 0.62 & 0 \\
& UM3 & 86.30 & 98.80 & 0 & 17.50 & 0.62 & 0 \\
& UM4 & 76.30 & 91.30 & 0 & 5.0 & 0.62 & 0 \\
& p-value & 0.81 & 0.50 & 0 & 0.18 & 1.00 & 0 \\
& LCV & 26.72 & 10.59 & 0 & 70.18 & 0 & 0 \\
\hline
\end{tabular}

Note. $\mathrm{AEZ}=$ Agro-ecological zones, $\mathrm{UM}=$ Upper midland, $\mathrm{LH}=$ Lower highland, $\mathrm{NLB}=$ Northern leaf blight, $\mathrm{GLS}=$ Gray leaf spot, MSD = Maize streak disease, $\mathrm{CR}=$ Common rust, $\mathrm{HS}=$ Head smut, $\mathrm{CS}=$ Common smut. 


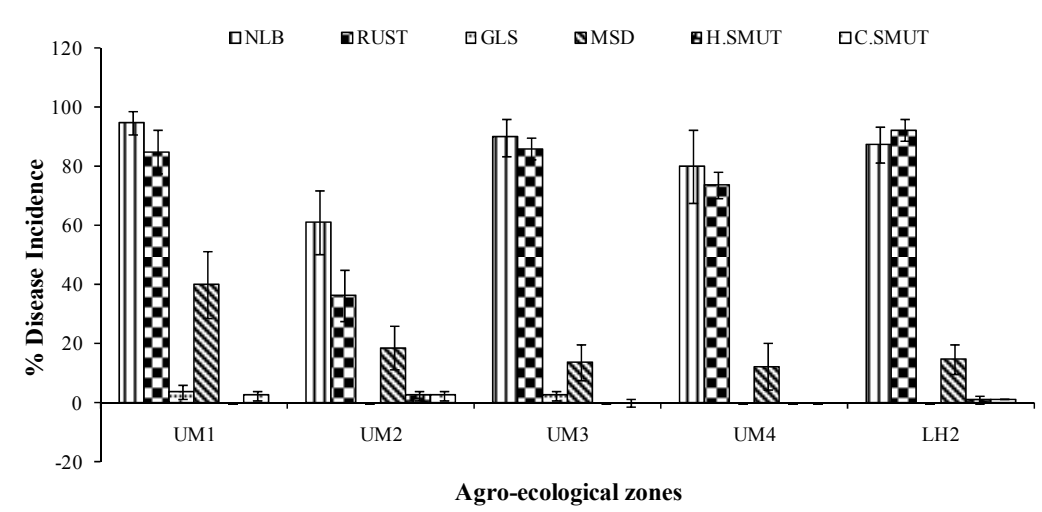

Figure 2. Incidence of most common diseases of maize on different agro ecological zones surveyed in Kenya Note . AEZ $=$ Agro-ecological zones, $\mathrm{UM}=$ Upper midland, $\mathrm{LH}=$ Lower highland, NLB $=$ Northern leaf blight, GLS $=$ Gray leaf spot, MSD = Maize streak disease, $\mathrm{HS}=$ Head smut, $\mathrm{CS}=$ Common smut.

\subsubsection{Disease Severity}

The severity of common rust was significantly higher in UM1 compared to UM2 and UM3. There was no significant difference in severity of common rust between UM4 and UM2 of Kiambu County. No significant differences were observed between any agro ecological zones in Embu County for common rust. In Nakuru there was significant difference between LH2 and UM4 and between UM3 and UM4 for common rust (Table 6). There was no significant difference in severity for maize streak disease in all agro ecological zones across the counties.

Common rust had the highest severity score across the agro ecological zones (Figure 3). In UM1, UM2, UM4 and LH2 there was a significant difference between the four diseases, NLB, common rust, MSD and GLS. There was a significant difference in UM3 between common rust and NLB. No significant differences were observed between MSD and GLS.

Table 6. Disease severity of NLB, common rust, GLS and maize streak disease in different AEZs in Kiambu, Embu and Nakuru Counties

\begin{tabular}{llllll}
\hline County & AEZ & NLB & Common Rust & GLS & MSD \\
\hline Kiambu & UM1 & 0.70 & 2.00 & 1.12 & 1.55 \\
& UM2 & 0.15 & 1.15 & 1.00 & 1.29 \\
& UM4 & 0.76 & 1.52 & 0.97 & 1.20 \\
& p-value & 0.03 & 0.001 & 0.25 & 0.47 \\
& \%CV & 48.30 & 0 & 11.70 & 29.40 \\
& LSD & 0.45 & 0.14 & 1.21 & 0.68 \\
\hline Embu & UM1 & 0.475 & 1.75 & 1.00 & 1.32 \\
& UM2 & 0.55 & 1.60 & 1.00 & 1.17 \\
& UM3 & 0.67 & 1.75 & 1.15 & 1.06 \\
& p-value & 0.18 & 0.69 & 0.13 & 0.26 \\
& \%CV & 23.70 & 16.50 & 9.50 & 16.90 \\
& LSD & 0.23 & 0.48 & 0.17 & 0.35 \\
\hline Nakuru & LH2 & 0.51 & 2.16 & 1.00 & 1.06 \\
& UM3 & 0.48 & 2.29 & 1.00 & 1.12 \\
& UM4 & 0.38 & 2.04 & 1.00 & 1.02 \\
& p-value & 0.13 & 0.49 & 0 & 0.15 \\
& \%CV & 21.27 & 12.88 & 0 & 5.77 \\
& LSD & 0.17 & 0.48 & 0 & 0.11 \\
\hline
\end{tabular}

Note. $\mathrm{AEZ}=$ Agro-ecological zones, $\mathrm{UM}=$ Upper midland, $\mathrm{LH}=$ Lower highland, NLB $=$ Northern leaf blight, $\mathrm{GLS}=$ Gray leaf spot, MSD = Maize streak disease, $\mathrm{HS}=$ Head smut, $\mathrm{CS}=$ Common smut. 


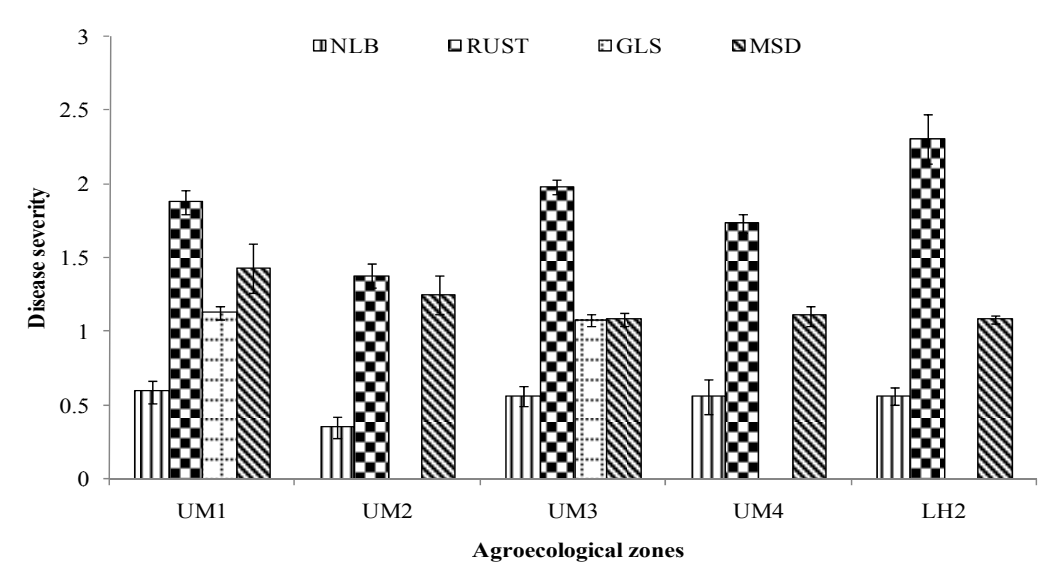

Figure 3. Severity of common maize diseases in different agro ecological zones surveyed in Kenya

Note. $\mathrm{AEZ}=$ Agro-ecological zones, $\mathrm{UM}=$ Upper midland, $\mathrm{LH}=$ Lower highland, NLB $=$ Northern leaf blight, GLS $=$ Gray leaf spot, MSD $=$ Maize streak disease.

\subsection{Molecular Characterization of Maize Streak Virus}

\subsubsection{PCR Results and Product Purification}

A total of 30 samples were collected, out of which 8 tested positive to MSV using primers G4F/G6R. PCR amplifications generated the expected $900 \mathrm{bp}$ fragment. No amplification products were generated from some of the maize samples even though they had symptoms similar to those observed in maize infected with MSV. The bands from four of the positive samples were weak, indicating low quantities of PCR products. The remaining 4 samples with strong bands were purified and submitted for sequencing.

\subsubsection{Sequence Analysis and Comparisons}

The nucleotide and derived amino acid sequences of the four Kenyan MSV isolates were compared within themselves and with other MSV isolates obtained from the GenBank. Pairwise comparisons of nucleotide sequences from the four Kenya isolates gave identities ranging from 99 to $100 \%$, indicating that they are isolates of the same virus. Comparisons with MSV nucleotide sequences from other parts of the world also gave 99 to $100 \%$ sequence similarities to the MSV-A strains. Phylogenetic analysis using nucleotide sequences resulted in only one group of isolates being visually distinguished (Figure 4).

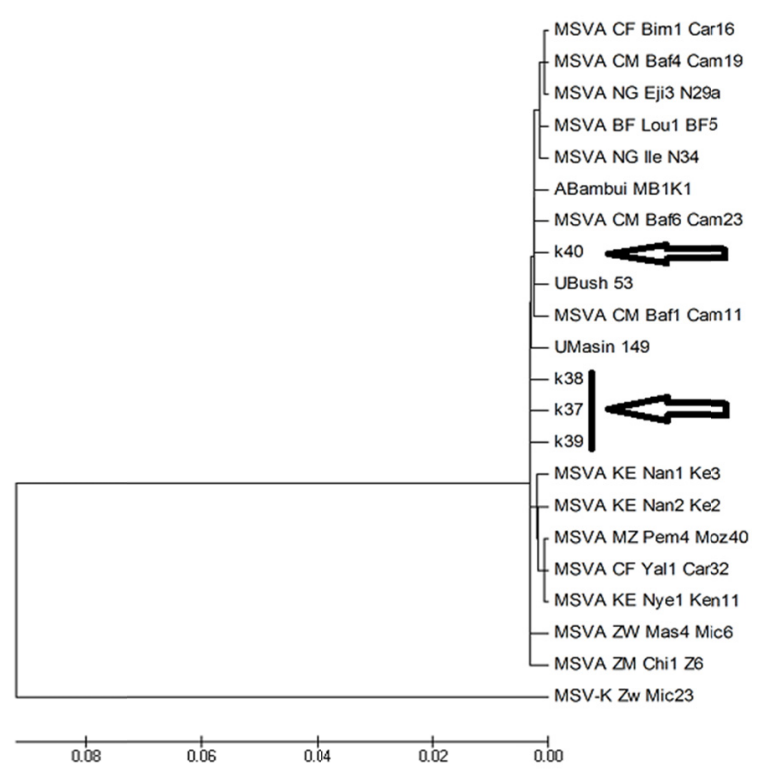

Figure 4. Phylogenetic relationships of Maize streak virus isolates from Kenya and others from other parts of the world. Maize streak virus isolate MSV-K from Zimbabwe was used as an outgroup

Note. $\leftarrow$ Kenyan isolates. 


\section{Discussion}

This study was carried out to assess the distribution, incidence and severity of major maize diseases and to characterize different MSV isolates collected from different maize growing regions of Kenya. The most important foliar diseases identified from the study were northern leaf blight, common rust and maize streak disease. Similar studies identified northern leaf blight, common rust and maize streak as important diseases in Kenya (Mwangi, 1998). The three diseases were severe in the counties surveyed and posed a great threat to maize production. Higher altitudes in Kiambu and Embu had high incidences of MSD, NLB and rust. Northern leaf blight was also recorded in all the counties surveyed with relatively high incidences. Previous studies had similar results where McLeod et al. (2001) reported that farmers in Kiambu ranked MSD as a major maize production constraint and the most difficult problem of maize to deal with. Kinyua (2004) and Muiru (2008) reported NLB to be common in many regions in Kenya confirming that the disease has a wide ecological distribution. Northern leaf blight is common in areas with high annual rainfall of about $1100 \mathrm{~mm}$, high humidity and cool temperatures of between 11 to $27{ }^{\circ} \mathrm{C}$. These conditions create ideal environment for infection and dispersal of inoculum (Mwangi, 1998). Disease incidence and severity varied from one farm to another even in the same agro-ecological zones. This could be attributed to crop management practices such as diseases and weed management and crop rotation that reduces the build up of disease inoculum as was also reported by Cunfer et al. (2006) and Handiseni et al. (2008).

Common rust was widely distributed in all the agro-ecological zones and was most serious in Nakuru as also reported by Mwangi (1998), with incidences of between $91 \%$ and $98 \%$. The disease infects the leaves and sheath and the disease is severe on late planted crop. Maize streak disease was highest in Kiambu with 12 farms out of the 30 farms recording the disease. This could be attributed to the farming systems in Kiambu where farmers plant maize almost all the time in small acreages compared to Nakuru where farms maintain cropping seasons and operate large acreages.

From the study, high level of correlations was observed for prevalence of the different diseases, their incidence and severity, and where there were high percentages of disease prevalence, disease incidence and severity were equally high. Agro-ecological zone UM2 in Kiambu had significantly low scores for the various diseases. This zone is characterized by low temperatures between 18 and $21{ }^{\circ} \mathrm{C}$ and low humidly. These conditions, especially low humidity, are not favourable for the fungal pathogens to proliferate (Jaetzold et al., 2006).

Farmers in Nakuru which is in the Rift Valley region plant more hybrids than farmers in both Embu and Kiambu. Farmers in Nakuru grow maize as a cash crop and most have adopted the use of certified seeds. Maize farming in Nakuru is different from Embu and Kiambu. In Nakuru, most farmers are large scale and hence practice mechanized farming. In Kiambu, farms are small with many farmers planting local varieties of maize since maize is not considered a very serious crop in the area. In the management of the diseases half of the farmers interviewed in Kiambu and Embu managed the diseases by uprooting infected crops compared to Nakuru where they don't uproot. Uprooting is the common practice encouraged in the management of MSV (Mwangi, 1998).

Geminivirus degenerate primers yielded the expected PCR amplicons of approximately 900bp for eight of the thirty samples analyzed. There was no amplification in 24 symptomatic samples, indicating that either the primers were not broad enough to amplify some of the viruses present, or the symptoms were caused by other viruses different from MSV. Recent outbreaks of MLN disease (Wangai et al., 2012) indicate the possible presence of other viruses that are not related to MSV but may cause similar symptoms.

The amplified fragments represented partial sequences from open reading frame $\mathrm{C} 2 / \mathrm{C} 1$ of Geminiviruses. The PCR products from four isolates were sequenced and used for comparative studies. The four sequences generated were aligned together with each other and also with eighteen other sequences previously described from different parts of the world. Phylogenetic analysis indicated that the four Kenyan MSV sequences were closely related to each other. When the four sequences were compared with other MSV sequences from the rest of the world, they were all related to the maize-adapted MSV-A type and all clustered with the MSV-A subtypes identified previously in a 1999 survey of African MSV diversity (Martin et al., 2009). Similar studies carried around the East African region had concluded that the main strain of MSV in the region belong to the MSV-A subtype (Owor et al., 2007).

The four MSV isolates were collected from infected maize. However, other grasses are also known to be hosts of different strains of MSV (Willment et al., 2001). Monjane et al. (2011) indicated that the strains infecting the grasses are different from those infecting maize. The different virus strains are known to recombine and may result to more virulent virus strains. There is need to determine the diversity between MSV strains infecting the different grasses in the country and map out their distribution. Such studies will be important in determining if 
there is possible recombination occurring within the geminiviruses infecting grasses and their possible impact to maize production in the future. Information generated will also be used to inform regulators on possible restrictions of infected materials to avoid introduction of new strains into new areas. The East Africa region is known to be a hot spot for MSV (Owor, 2008). Monjane et al. (2011) suggested that regular analysis of MSV-A genome within such diversification hot spots should be used to monitor the emergence of future MSV-A lineages that could affect maize cultivation in Africa.

\section{Conclusions}

The results from this study indicate that maize varieties planted by the farmers in different maize growing regions of Kenya were susceptible to the major maize diseases and it was clear that most of the farmers were not able to identify these diseases. Some farmers were also planting maize varieties that may not be suited for the respective areas, denying the farmers an opportunity to realize the potential yields from such varieties. Maize diseases have a wide distribution in the various agro-ecological zones and there is need to institute various disease management strategies to curb the losses associated with these diseases. The Kenyan isolates of MSV were found to be highly similar to one another and to others infecting maize from different regions of the world. This may be an indication of low MSV diversity and a possibility of limited recombination with other geminiviruses infecting other grasses in the country. Low virus diversity in a region is good for breeders since developed resistant varieties can be adopted over a wider region and possibility of emergence of resistant breaking strains is also low.

The study revealed that the major foliar diseases of maize are widespread in most of the areas where maize is grown in Kenya and therefore, there is need to institute measures to manage these diseases and reduce the associated losses. Farmers should be advised to observe closed seasons to break the disease cycle and reduce the disease inocula. In deployment of resistance varieties, there is need to take into consideration the disease distribution and to ascertain the pathogen races so as to develop more durable resistance. There is need for an extensive survey covering different regions of the country where maize is grown to be able comprehensively establish the diversity and strain distribution of MSV in Kenya.

\section{References}

Alegbejo, M. D., Olojede, S. O., Kashina, B. D., \& Abo, M. E. (2002). Maize streak mastrevirus in Africa: Distribution, transmission, epidemiology, economic significance and management strategies. Journal of Sustainable Agriculture, 19, 35-45. https://doi.org/10.1300/J064v19n04_05

Bosque-Perez, N. A. (2000). Eight decades of Maize streak virus research. Virus Research, 71, 107-121. https://doi.org/10.1016/S0168-1702(00)00192-1

CIMMYT Maize Program. (2004). Maize Diseases: A Guide for Field Identification (4th ed.). Mexico, D.F.: CIMMYT.

Cunfer, B. M., Buntin, G. D., \& Phillips, D. V. (2006). Effect of crop rotation on take-all of wheat in double-cropping systems. Plant Disease, 90, 1161-1166. https://doi.org/10.1094/PD-90-1161

Danson, J., Lagat, M., Kimani, M., \& Kuria, A. (2008). Quantitative trait loci (QTLs) for resistance to gray leaf spot and common rust diseases of maize. African Journal of Biotechnology, 7, 3247-3254.

Dellaporta, S. L., Wood, J., \& Hicks, H. B. (1983). A plant DNA minipreparation: Version II. Plant Molecular Biology Reporter, 1, 19-21. https://doi.org/10.1007/BF02712670

Elliott, C., \& Jenkins, M. T. (1946). Helminthosporium turcicum leaf blight of corn. Phytopathology, 36, 660-668.

EPZA (Export Processing Zone Authority). (2005). Grain production in Kenya. Nairobi, Kenya. Retrieved from http://www.epzakenya.com/UserFiles/File/GrainReport.pdf

Gichuru, L., Njoroge, K., Ininda, J., \& Lorroki, P. (2011). Combining ability of grain yield and agronomic traits in diverse maize lines with Maize streak virus resistance for Eastern Africa region. Agriculture and Biology Journal of North America, 2, 432-439. https://doi.org/10.5251/abjna.2011.2.3.432.439

Handiseni, M., Sibiya, J., Ogunlela, V., \& Koomen, I. (2008). Comparative study of the Effect of different weed management strategies on disease severity and Marketable yield of paprika (Capsicum annuum L.) in the smallholder farming sector of Zimbabwe. Journal of Plant Protection Research, 48(1). https://doi.org/ $10.2478 / \mathrm{v} 10045-008-0011-\mathrm{z}$ 
Jaetzold, R., Schmidt, H., Hornet, B., \& Shisanya, C. (2006). Farm Management Handbook of Kenya. Ministry of Agriculture, Kenya and German Agency Technical Cooperation team (CTZ).

Jeanmougin, F., Thompson, J. D., Gouy, M., Higgins, D. G., \& Gibson, T. J. (1998). Multiple sequence alignment with Clustal X. Trends in Biochemical Sciences Journal, 23, 403-405. https://doi.org/10.1016/ S0968-0004(98)01285-7

Keya, S., \& Rubaihayo, P. (2013). Progress on on-farm production and productivity in East Africa Community; 50 years after independence (Kilimo trust technical paper No. 8). International Symposium on Agriculture, EAC Partner States at 50 Years.

Kinyua, Z. M. (2004). Genetic structure, virulence characteristics and survival of Cercospora populations causing maize grey leaf spot in Kenya (PhD Thesis, Royal Holloway University of London).

Kinyua, Z. M., Smith, J. J., Kibata, G. N., Simons, S. A., \& Langat, B. C. (2010). Status of gray leaf spot disease in Kenyan maize production ecosystems. African Crop Science Journal, 18, 183-194.

Kyetere, D. T., Ming, R., McMullen, M. D., Pratt, R. C., Brewmaker, J., \& Musket, T. (1999). Genetic analysis of tolerance to Maize streak virus in maize. Genome, 42, 20-26. https://doi.org/10.1139/g98-099

Lagat, M., Danson, J., Kimani, M., \& Kuria, A. (2008). Quantitative trait loci for resistance to Maize streak virus disease in maize genotypes used in hybrid9 development. African Journal of Biotechnology, 7, 2573-2577.

Magenya, O. E. V., Mueke, J., \& Omwega, C. (2008). Significance and transmission of Maize streak virus disease in Africa and options for management. African Journal of Biotechnology, 7, 4897-4910. https://doi.org/10.5897/AJB08.077

Martin, D. P., \& Shepherd, D. N. (2009). The epidemiology, economic impact and control of maize streak disease. Food Security, 1, 305-315. https://doi.org/10.1007/s12571-009-0023-1

Martin, D. P., Willment, J. A., Billharz, R., Velders, R., Odhiambo, B., Njuguna, J., ... Rybicki, E. P. (2001). Sequence diversity and virulence in Zea mays of Maize streak virus isolates. Virology, 288, 247-255. https://doi.org/10.1006/viro.2001.1075

Mboya, R., Tongoona P., Derera J., Mudhara, M., \& Langyintuo, A. (2011). The dietary importance of maize in Katumba ward, Rungwe district, Tanzania, and its contribution to household food security. African Journal of Agricultural Research, 6, 2617-2626.

McLeod, A., Njuguna, J., Musembi, F., Maina, J., \& Miano, D. (2001). Farmer strategies for maize growing, Maize streak virus control and feeding of smallholder dairy cattle in Kiambu District, Kenya. Results of a Rapid Rural Appraisal held in April and May 2001. First Technical Report of NRIL Project R7955/ZC0180.

Monjane, A. L., Va da Walt, E., Varsani, A., Rybicki, A. P., \& Martin, D. P. (2011). Recombination hotspots and host susceptibility modulate the adaptive value of recombination during Maize streak virus evolution. BMC Evolutionary Biology, 11, 350. https://doi.org/10.1186/1471-2148-11-350

Muiru, W. M. (2008). Histological studies and characterization of races of Exserohilum turcicum the causal agent of Northern Leaf Blight of Mize in Kenya ( $\mathrm{PhD}$ Thesis, University of Nairobi, Kenya).

Muiru, W. M., Koopmann, B., Tiedemann, A. V., Mutitu, E. W., \& Kimenju, J. W. (2010). Race typing and evaluation of aggressiveness of Exserohilum turcicum isolates of Kenya, German and Austrian Origin. World Journal of Agricultural Sciences, 6, 277-284.

Mwangi, S. M. (1998). Status of northern leaf blight, Phaeosphaeria maydis leaf spot, southern leaf blight, rust, Maize streak virus and physiological specialization of Exserohilum turcicum in Kenya (PhD Thesis, Virginia Polytechnic Institute and State University).

Nzuve, F., Githiri, S., Mukunya, D. M., \& Gethi, J. (2013). Combining abilities of maize inbred lines for grey leaf spot (GLS), grain yield and selected agronomic traits in Kenya. Journal of Plant Breeding and Crop Science, 5, 41-47. https://doi.org/10.5897/JPBCS12.056

Ouma, J. O., \& De Groote, H. (2011). Maize varieties and production constraints capturing farmers' perceptions through participatory rural appraisals (PRAs) in Eastern Kenya. Journal of Development and Agricultural Economics, 3, 679-688.

Owor, B. (2008). Maize streak virus (MSV) diversity in Uganda and the assessment of gene silencing as a tool for development of resistance to MSV (PhD Thesis, University of Cape Town). 
Owor, B. E., Martin, D. P., Shepherd, D. N., Edema, R., Monjane, A. L., Rybicki, E. P., ... Varsani, A. (2007). Genetic analysis of Maize streak virus isolates from Uganda reveals widespread distribution of a recombinant variant. Journal of General Virology, 88, 3154-3165. https://doi.org/10.1099/vir.0.83144-0

Pratt, R. C., \& Gordon, S. G. (2006). Breeding for resistance to maize foliar pathogens. Plant Breeding Review, 27, 119-174.

Tamura, K., Dudley, J., Nei, M., \& Kumar, S. (2007). MEGA4: Molecular Evolutionary Genetics Analysis (MEGA) software version 4.0. Molecular Biology and Evolution, 24, 1596-1599. https://oi.org/10.1093/ molbev/msm092

Tefera, T., Mugo, S., Tende, R., \& Likhayo, P. (2011). Methods of screening maize for resistance to stem borers and post-harvest insect pests (pp. 90-115). The 30 ${ }^{\text {th }}$ Annual Corn and Sorghum Research Conference, CIMMYT, Nairobi, Kenya.

Tumusiime, E., De-Groote, H., Vitale, J., \& Adam, B. (2010). The cost of coexistence between Bt maize and open-pollinated maize varieties in lowland coastal Kenya. AgBioForum, 13, 208-221.

Van Antwerpen, T., \& Rutherford, R. S. (2008). Increased risk of new infection in the South African Sugarcane industry: Preparing for the future. Proceedings of the South African Sugar Technologists'Association, 81, 365-380.

Varsani, A., Shepherd, D. N., Monjane, A. L., Owor, B. E., Erdmann, J. B., Rybicki, E. P., ... Martin, D. P. (2008). Recombination, decreased host specificity and increased mobility may have driven the emergence of Maize streak virus as an agricultural pathogen. Journal of General Virology, 89, 2063-2074. https://doi.org/10.1099/vir.0.2008/003590-0

Wambugu, F., \& Wafula, J. (2000). Advances in Maize streak virus disease research in Eastern and Southern Africa. Workshop Report 15-17 September 1999, KARI and ISAAA Africa Center, ISAAA Brief Number 16-Ithaca. International Service for the Acquisition of Agric-biotech Applications, NY.

Wangai, A. W., Redinbaugh, M. G., Kinyua, Z. M., Miano, D. W., Leley, P. K., Kasina, M., ... Jeffers. (2012). First Report of Maize chlorotic mottle virus and Maize Lethal Necrosis in Kenya. Plant Disease, 96, 1582. https://doi.org/10.1094/PDIS-06-12-0576-PDN

Willment, J. A., Martin, D. P., \& Rybicki, E. P. (2001). Analysis of the diversity of African streak mastreviruses using PCR-generated RFLP's and partial sequence data. Journal of Virology Methods, 93, 75-87. https://doi.org/10.1016/S0166-0934(00)00299-8

\section{Copyrights}

Copyright for this article is retained by the author(s), with first publication rights granted to the journal.

This is an open-access article distributed under the terms and conditions of the Creative Commons Attribution license (http://creativecommons.org/licenses/by/4.0/). 